\title{
Covid-19 pneumonia: Timing of pneumomediastinum and pneumothorax in 11 patients
}

\author{
Mostafa Al Turk, Maria Mitri, Kawthar Jarrah, Joanna Abi Chebl, Georges Juvelekian \\ Saint George Hospital University Medical Center, Beirut, Lebanon
}

Received: May 24, 2021

Accepted: July 8, 2021

Online Published: August 7, 2021

DOI: $10.5430 / \mathrm{dcc} . \mathrm{v} 8 \mathrm{n} 2 \mathrm{p} 1$

URL: https://doi.org/10.5430/dcc.v8n2p1

\begin{abstract}
Purpose: As the pandemic continues, many complications, previously recognized as rare, are now being reported as more than frequent complications of Covid-19 pneumonia. Of those, pneumomediastinum and pneumothorax are gaining attention. Their mechanism of occurrence/trigger is not fully understood, but the timing at which they occur is unclear.

Methods: This is a case series of 11 Covid-19 patients with pneumomediastinum; retrospectively, we shed light on some of the patients' characteristics, the role of mechanical ventilation, and the timing of pneumomediastinum after initiation of mechanical ventilation.

Results: We found that despite following the lung-protective strategy and despite keeping a plateau pressure at an acceptable range, most of our patients had an acute event around the same timing of mechanical ventilation.

Conclusions: The similar timing raises questions about other risk factors that remain unknown. Timing and steroids can contribute to the higher incidence of these complications.
\end{abstract}

Key Words: COVID-19, Pneumomediastinum, Pneumothorax, ARDS, Respiratory failure, Hypoxemia, Barotrauma, Lungprotective strategy, Plateau pressure

\section{INTRODUCTION}

Covid-19 is an infectious disease caused by the SARS-COV2, a member of the family Coronaviridae. This virus has a wide range of presentations and involves different body organs. The respiratory presentation ranges from mild respiratory illness to severe form as acute respiratory distress syndrome (ARDS). ${ }^{[1,2]}$

Besides the use of the RT-PCR assay to detect the viral genetic material from the upper respiratory tract, a CT scan of the chest assists in diagnosing Covid-19 infection and can help detect complications associated with it. The characteristic radiological features associated with Covid-19 infection are ground-glass opacities with peripheral, subpleural, and lower lobes predominance and/or occasional bilateral multiple lobar/subsegmental consolidations. ${ }^{[3]}$

The respiratory complications reported with Covid-19 disease include but are not limited to pneumomediastinum, pneumothorax, subcutaneous emphysema, and pulmonary embolism. Pneumothorax and pneumomediastinum usually occur in patients on positive pressure ventilation (invasive or non-invasive) or have a history of respiratory illnesses. ${ }^{[4]}$

Pneumothorax is defined by air in the pleural cavity; hence the intrapleural pressure increases, causing a reduction in lung volumes. There are different types: spontaneous, traumatic, and iatrogenic. The majority of pneumothoraces that occur in critically ill patients are either secondary to baro-

*Correspondence: Maria Mitri; Email: maria.mitri@ hotmail.com; Address: Saint George Hospital University Medical Center, Beirut, Lebanon. 
trauma or traumatic pneumothorax after injury to the thorax, like during surgery. The presumed pathophysiological mechanism is a bullae formation followed by an acute inflammation causing obstruction of small airways and an increase in alveolar pressure. This result in air leak and gas accumulated around the hilum causing a pneumomediastinum and pneumothorax. The incidence and the prognostic significance of these complications are still not well known.

We present here a case series of 11 critically ill patients admitted for management of moderate or severe ARDS due to Covid-19 with a new pneumothorax and/or pneumomediastinum.

\section{Case presentation}

Ethical approval was obtained from the IRB/Ethical Research Committee at our university medical center (hospital) (IRBREC/O/025-21/1121).

The electronic medical records of 218 patients Covid-19 positive admitted to the hospital between March 2020, and
January 2021 were reviewed, and patients with either a pneumothorax, pneumomediastinum, or both were included in this case series.

Details collected from the medical record included: demographics (age and sex), smoking history, duration of symptoms, radiological findings on the day of admission, type of event, date of detection, use of positive pressure ventilation, use of steroids, and whether a chest tube was inserted or not. Patient consent was waived since this was a retrospective study.

Concerning imaging, we report a severity score assessed on chest scans where the percentage of involvement of each lung lobe correspond to certain points (0\%: 0 points, $1 \%-25 \%$ : 1 point, $26 \%-50 \%: 2$ points, more than 50\%: 3 points) with a maximum score of 15 .

In our case series, we present 11 patients with moderate to severe covid-19 pneumonia. Their average age was 45 years. We had one female and ten males. The patient's characteristics are summarized in Table 1.

Table 1. Patient characteristics and findings

\begin{tabular}{|c|c|c|c|c|c|c|c|c|c|c|}
\hline & $\begin{array}{l}\text { Age } \\
\text { (sex) }\end{array}$ & $\begin{array}{l}\text { Smoking } \\
\text { History }\end{array}$ & $\begin{array}{l}\text { Duration of } \\
\text { Symptoms prior } \\
\text { to presentation }\end{array}$ & $\begin{array}{l}\text { Chest CT findings on } \\
\text { admission (Severity } \\
\text { Score) }\end{array}$ & $\begin{array}{l}\mathrm{PaO}_{2} \text { at } \\
\text { admission }\end{array}$ & $\begin{array}{l}\text { Type of } \\
\text { MV Used }\end{array}$ & $\begin{array}{l}\text { Days } \\
\text { from MV } \\
\text { till event }\end{array}$ & Type of Event & Management & Outcome \\
\hline Patient 1 & $60(\mathrm{~F})$ & 10-pack-year & 7 days & $\begin{array}{l}\text { Diffuse bilateral GGO } \\
(10 / 15)\end{array}$ & $\begin{array}{l}55 \mathrm{mmHg} \\
\text { on RA }\end{array}$ & IMV & 9 & Pneumomediastinum & $\begin{array}{l}\text { Right chest } \\
\text { tube }\end{array}$ & Death \\
\hline Patient 2 & $52(\mathrm{M})$ & None & 7 days & $\begin{array}{l}\text { Diffuse bilateral GGO } \\
(13 / 15)\end{array}$ & $\begin{array}{l}56 \mathrm{mmHg} \\
\text { on RA }\end{array}$ & IMV & 10 & Left pneumothorax & $\begin{array}{l}\text { Left chest } \\
\text { tube }\end{array}$ & Death \\
\hline Patient 3 & $58(\mathrm{M})$ & None & 4 days & $\begin{array}{l}\text { Diffuse bilateral GGO } \\
(12 / 15)\end{array}$ & $\begin{array}{l}55 \mathrm{mmHg} \\
\text { on RA }\end{array}$ & IMV & 10 & Pneumomediastinum & $\begin{array}{l}\text { Right chest } \\
\text { tube }\end{array}$ & Death \\
\hline Patient 4 & $56(\mathrm{M})$ & None & 21 days & $\begin{array}{l}\text { Diffuse bilateral GGO } \\
(15 / 15)\end{array}$ & $\begin{array}{l}97 \mathrm{mmHg} \\
\text { on } 15 \mathrm{~L} \\
\text { NRFM }\end{array}$ & None & -- & Pneumomediastinum & Observation & $\begin{array}{l}\text { Discharge } \\
\text { home }\end{array}$ \\
\hline Patient 5 & $72(\mathrm{M})$ & Ex-smoker & 3 days & $\begin{array}{l}\text { Diffuse bilateral GGO } \\
(7 / 15)\end{array}$ & $\begin{array}{l}70 \mathrm{mmHg} \\
\text { on } 30 \mathrm{~L}\end{array}$ & $\begin{array}{l}\text { NIV then } \\
\text { IMV }\end{array}$ & 10 & Pneumomediastinum & $\begin{array}{l}\text { Right chest } \\
\text { tube }\end{array}$ & $\begin{array}{l}\text { Discharge } \\
\text { home }\end{array}$ \\
\hline Patient 6 & $63(\mathrm{M})$ & None & 14 days & $\begin{array}{l}\text { Multifocal peripheral } \\
\text { GGO (12/15) }\end{array}$ & $\begin{array}{l}57 \mathrm{mmHg} \\
\text { on RA }\end{array}$ & $\begin{array}{l}\text { NIV then } \\
\text { IMV }\end{array}$ & 10 & Pneumomediastinum & $\begin{array}{l}\text { Left chest } \\
\text { tube }\end{array}$ & $\begin{array}{l}\text { Discharge } \\
\text { home }\end{array}$ \\
\hline Patient 7 & $45(\mathrm{M})$ & 20-pack-year & 7 days & $\begin{array}{l}\text { Bilateral interstitial } \\
\text { infiltrates [chest x-ray] }\end{array}$ & N/A & IMV & 3 & Pneumomediastinum & $\begin{array}{l}\text { Bilateral } \\
\text { Chest tubes }\end{array}$ & Death \\
\hline Patient 8 & $39(\mathrm{M})$ & None & 12 days & $\begin{array}{l}\text { Multifocal GGO and } \\
\text { consolidations (14/15) }\end{array}$ & $\begin{array}{l}59 \mathrm{mmHg} \\
\text { on RA }\end{array}$ & NIV & 9 & Pneumomediastinum & Observation & $\begin{array}{l}\text { Discharge } \\
\text { home }\end{array}$ \\
\hline Patient 9 & $65(\mathrm{M})$ & None & 12 days & Diffuse GGOs (15/15) & $\begin{array}{l}43 \mathrm{mmHg} \\
\text { on RA }\end{array}$ & $\begin{array}{l}\text { NIV then } \\
\text { IMV }\end{array}$ & 11 & Left pneumothorax & $\begin{array}{l}\text { Left chest } \\
\text { tube }\end{array}$ & Death \\
\hline Patient 10 & $60(\mathrm{M})$ & N/A & 7 days & $\begin{array}{l}\text { Multifocal GGO with } \\
\text { upper lobes } \\
\text { consolidations (13/15) }\end{array}$ & $\begin{array}{l}41 \mathrm{mmHg} \\
\text { on } 15 \mathrm{~L} \\
\text { NRFM }\end{array}$ & None & -- & Pneumomediastinum & Observation & $\begin{array}{l}\text { Discharge } \\
\text { home }\end{array}$ \\
\hline Patient 11 & $31(\mathrm{M})$ & None & 7 days & $\begin{array}{l}\text { Multifocal peripheral } \\
\text { GGO (14/15) }\end{array}$ & $\begin{array}{l}40 \mathrm{mmHg} \\
\text { on RA }\end{array}$ & IMV & 4 & Right pneumothorax & $\begin{array}{l}\text { Right chest } \\
\text { tube }\end{array}$ & Death \\
\hline
\end{tabular}

Of the 11 cases we presented, two patients had only pneumothorax; seven had the only pneumomediastinum, while the rest had both. All of the patients in this study were taking steroids (6mg dexamethasone IV once daily, except for patient 7, who was on methylprednisolone $30 \mathrm{mg}$ IV twice daily). Accordingly, the overall frequency for the study duration was $5 \%$, out of which $0.9 \%$ of the events occurred spontaneously (see Figure 1).
Two of our patients were neither on NIV nor mechanical ventilation at the time of the event and hence had a spontaneous occurrence which is uncommon. Both were males, non-smokers, and without any previous lung disease. Both of them only had pneumomediastinum, were managed conservatively, and were eventually discharged home (see Figure $2 \mathrm{a}$ and $2 \mathrm{~b})$. 


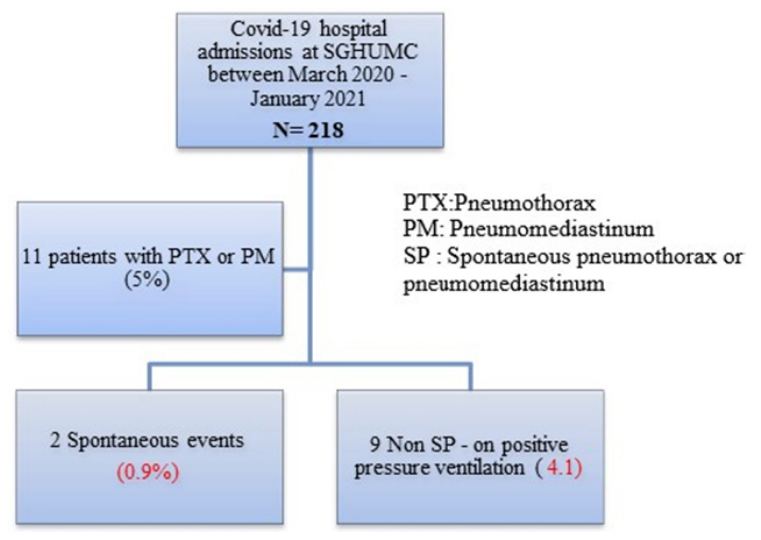

Figure 1. Flow chart with percentage of cases

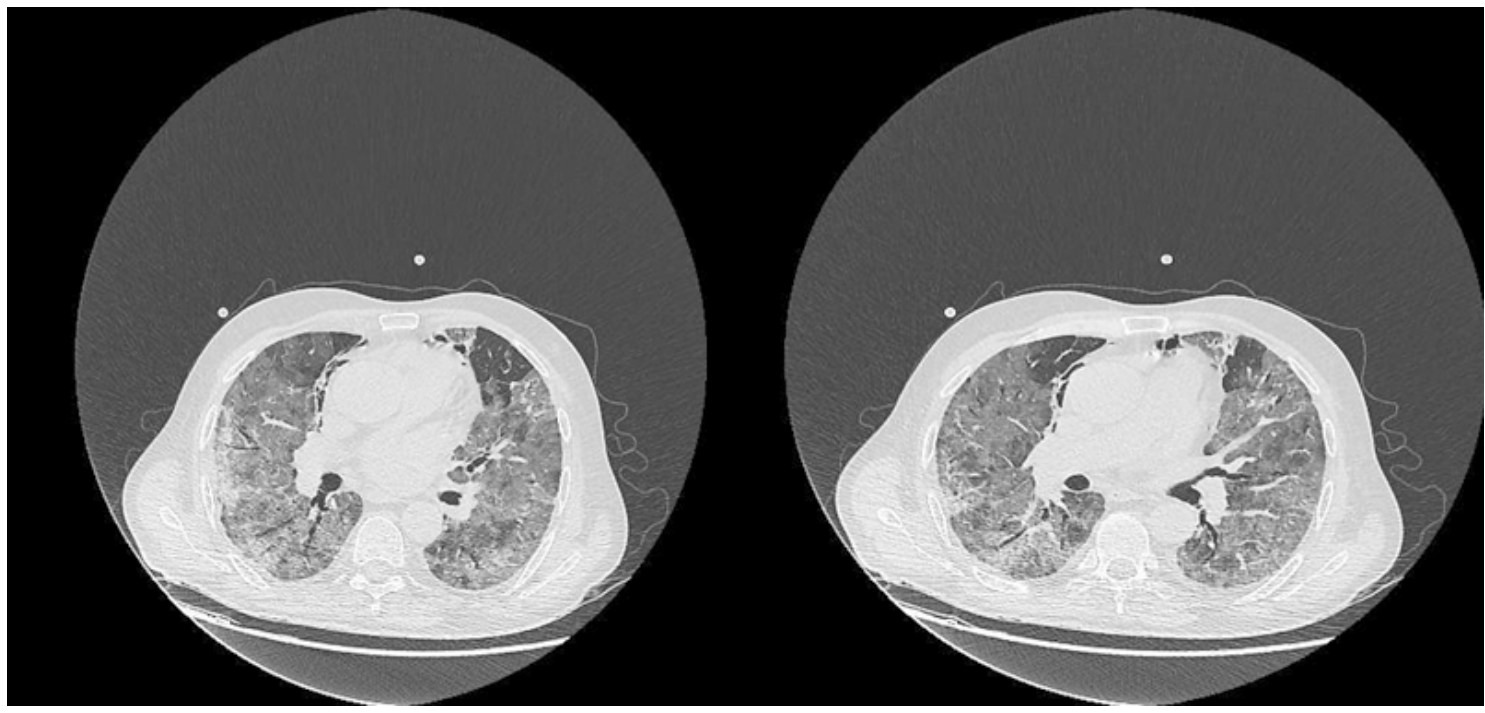

Figure 2. Axial slices of a chest CT (lung window) of a spontaneously breathing 56-year-old man with bilateral diffuse ground-glass opacities and spontaneous pneumomediastinum

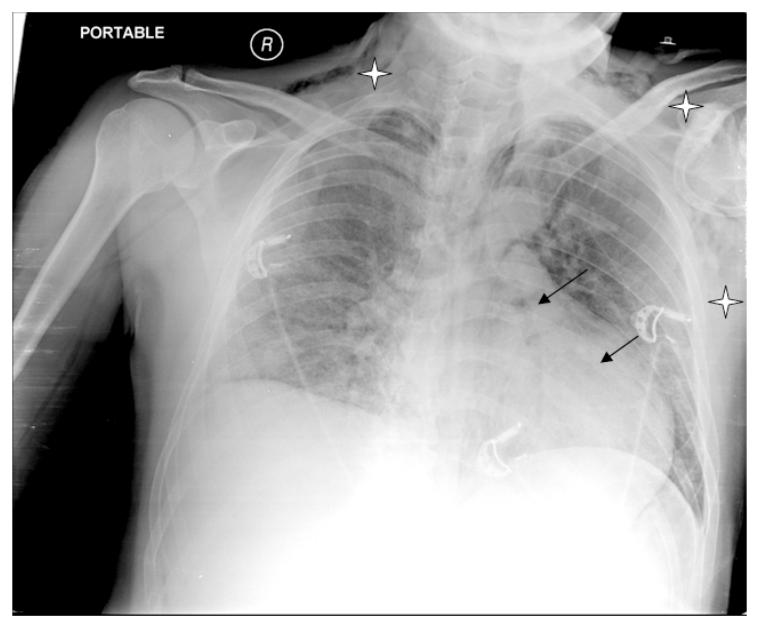

Figure 3. Pneumomediastinum (black arrows) and subcutaneous emphysema (asterisks) in a non-intubated 39-year-old male patient on Bipap (patient 8)
The rest of the patients were either receiving invasive or non-invasive mechanical ventilation. All intubated patients received mechanical ventilation with a low Plateau pressure and high peep settings. Remarkably, all patients had a pneumothorax or pneumomediastinum around the same time from the initiation of mechanical ventilation. The average date to develop a pneumomediastinum or pneumothorax was 8.4 days, with seven out of nine patients developing it at days 9 to 11 (see Table 1 and Figures 3 and 4). Furthermore, the timeframe between the onset of symptoms and the need for mechanical ventilation was also similar in all patients with a mean of 13,6 days (see Table 2). 
Table 2. Time between symptoms onset and initiation of MV in days along with settings at event occurrence

\begin{tabular}{lll}
\hline Patient & $\begin{array}{l}\text { Time between symptoms onset } \\
\text { and initiation of MV in days }\end{array}$ & MV settings \\
\hline 1 & 9 & TV 450, PEEP 10 \\
2 & 12 & TV 600, PEEP12 \\
3 & 10 & PC 20/PEEP 8 \\
4 & not applicable & 15L NRFM \\
5 & 13 & TV 570 PEEP 15 \\
6 & 18 & PC 20/PEEP 8 \\
7 & 10 & TV 480 PEEP 10 \\
8 & 18 & Bipap 16/8 \\
9 & 20 & Bipap 16/8 \\
10 & not applicable & 20 L NRFM \\
11 & 13 & TV 500 PEEP5 \\
\hline
\end{tabular}

\section{Discussion}

The world has been battling a pandemic since December of 2019. With more than 100 million confirmed cases of covid19 and more than 2.6 million deaths until now, the pandemic is still ongoing without any disease-specific therapy. ${ }^{[5]}$

What we present here today is in line with other world publications that have shown a higher-than-usual rate of pneumothorax/pneumomediastinum in patients with moderate to severe Covid-19 ARDS compared to non-Covid patients. In one of the recently published papers, ${ }^{[6]}$ the authors showed that the incidence of pneumothorax was higher in those who needed mechanical ventilation, and it correlates with death and worse outcomes such as longer hospital stay. In addition, spontaneous pneumothorax is unusual, but it is more frequent in the Covid population and can be associated with worse outcomes. ${ }^{[7,8]}$ We noticed that $5 \%$ of our Covid-19 admitted patients developed a pneumothorax and/or a pneumomediastinum, and $4.1 \%$ were treated with mechanical ventilation, whether invasive or non-invasive. This is compatible with other studies where one published series indicate that $3 \%$ of patients hospitalized with pneumonia had similar events in comparison to $6 \%$ of 202 mechanically ventilated patients in another paper. ${ }^{[9,10]}$ Moreover, as shown in Table 2, the time-lapse between symptoms and the need for mechanical ventilation was greater than ten days which is in conformity with the recent guidelines to avoid intubation when appropriate. To this date, the ideal timing for invasive mechanical ventilation remains controversial. Patients with moderate to severe covid are unlikely to improve and usually need invasive mechanical ventilation by the second week of their illness. ${ }^{[11]}$

Some pulmonary infections are known to cause pneumothorax and pneumomediastinum, and as it is now evident Covid-
19 pneumonia is associated with an intense inflammatory reaction and some pathology reports validating the destruction of the intra-luminal connective tissue within alveolar ducts and bronchioles, causing a weak area that could be related to the appearance of pneumothorax. ${ }^{[12]}$ The literature has been flooded with postulations about the mechanisms, including alveolar damage and rupture, causing interstitial emphysema and air dissection into the mediastinum. Straining maneuvers, mainly repetitive coughing as in the case of non-intubated patients with severe Covid-19 pneumonia, can also cause an increase in intrathoracic pressure creating subsequent alveolar rupture and ultimately leading to interstitial and subcutaneous emphysema. ${ }^{[13]}$ On the other hand, some case reports have been published on pneumomediastinum and/or pneumothorax in Covid-19 patients secondary to superimposed bacterial, fungal, and mycobacterial infections. Such infections can lead to necrotizing lung lesions and/or bronchopleural fistulas. $^{[14]}$ Another established cause of pneumothorax is barotrauma in patients on positive pressure ventilation; however, at our institution, we followed a lung-protective strategy, and all our mechanically ventilated patients had a low Plateau pressure $(<30 \mathrm{mmHg})$, were well sedated ( Richmond Agitation Sedation Scale daily assessment between 0 and -2) eliminating an additional trigger for pneumothorax or pneumomediastinum. These findings are in harmony with the results from another tertiary care university hospital where despite following a protective mechanical ventilator strategy, the occurrence of pneumothorax or pneumomediastinum was high and could be related to an increased mortality rate. ${ }^{[15]}$

In agreement with the above, pneumothorax or pneumomediastinum can arise, albeit if the intensivists respecting the established safety precautions. Consequently, Covid-19 patients are at higher risk of developing such events, which emphasizes other risk factors that remain unclear.

Our data analysis reveals that most of our patients, despite us following a low plateau pressure policy, developed pneumomediastinum around the tenth day after initiation of mechanical ventilation. However, to this date, there is no published data about the time frame during which pneumomediastinum occurs, whether in relation to the stage of the disease itself or in relation to the duration of mechanical ventilation. This raises the question of whether, for patients with Covid-19 ARDS, the duration of mechanical ventilation rather than the plateau pressures is responsible for the development of lung breach.

Other than the presumed timing of mechanical ventilation as a risk factor, the role of steroids in inducing a breach needs to be further investigated. It is known that 
steroids can delay or prevent the resolution of a pneumothorax/pneumomediastinum by inhibiting healing of the breached lung, ${ }^{[16]}$ and as noted earlier, all these patients were treated with steroids even before the occurrence of the event. In fact, steroids play a major role in the treatment of Covid19 moderate to severe pneumonia and are being used more frequently.

The best management of pneumomediastinum remains controversial. Although some of our patients had a chest tube inserted, we noticed spontaneous resolution in many cases of pneumomediastinum without any intervention, even without modifying the mechanical ventilation settings.
We have described the clinical and radiological characteristics of 11 patients suffering from moderate to severe Covid19 pneumonia, complicated by pneumomediastinum and pneumothorax. These characteristics highlight possible risk factors that may contribute to the development of such complications, including the presence or absence of mechanical ventilation, the duration of mechanical ventilation, and the use of steroids. The decisions to intervene, as well as the right timing to intervene, remain debatable, as some patients were managed successfully with conservative treatment only.

\section{CONFLicts OF INTEREST Disclosure}

The author declares no conflicts of interest.

\section{REFERENCES}

[1] Huang C, Wang Y, Li X, et al. Clinical features of patients infected with 2019 novel coronavirus in Wuhan, China. The Lancet. 2020; 395(10223): 497-506. https://doi.org/10.1016/S0140-673 6(20) 30183-5

[2] Zantah M, Dominguez Castillo E, Townsend R, et al. Pneumothorax in COVID-19 disease- incidence and clinical characteristics. Respir Res. 2020; 21(1). PMid:32938445. https://doi.org/10.1186/ s12931-020-01504-y

[3] Litmanovich D, Chung M, Kirkbride R, et al. Review of Chest Radiograph Findings of COVID-19 Pneumonia and Suggested Reporting Language. J Thorac Imaging. 2020; 35(6): 354-360. PMid:32520846. https://doi.org/10.1097/RTI.0000000000000541

[4] Elhakim T, Abdul H, Pelaez Romero C, et al. Spontaneous pneumomediastinum, pneumothorax and subcutaneous emphysema in COVID-19 pneumonia: a rare case and literature review. BMJ Case Rep. 2020; 13(12): e239489. PMid:33310838. https://doi.org/ $10.1136 / \mathrm{bcr}-2020-239489$

[5] Coronavirus disease (COVID-19) pandemic. World Health Organization. Available from: https://www.who.int/emerge ncies/diseases/novel-coronavirus-2019?gclid=EAIaIQ obChMIv46jpZ-47wIVFMPVCh3Rhgg0EAAYASAAEgKSNPD_BwE. Published 2021. Accessed March 17, 2021

[6] McGuinness G, Zhan C, Rosenberg N, et al. Increased Incidence of Barotrauma in Patients with COVID-19 on Invasive Mechanical Ventilation. Radiology. 2020 Nov; 297(2): E252-E262. PMid:32614258. https://doi.org/10.1148/radiol.2020202352

[7] Ghani M, Rodriguez-Ortiz Y, Ahmad D, et al. Spontaneous Pneumomediastinum in Patients with Sars-Cov-2 Virus (Covid-19). Chest. 2020; 158(4): A1231-A1232. https://doi.org/10.1016/j.ch est. 2020.08.1121

[8] Miró Ò, Llorens P, Jiménez S, et al. Frequency, Risk Factors, Clinical Characteristics, and Outcomes of Spontaneous Pneumothorax in Patients With Coronavirus Disease 2019: A Case-Control, Emergency Medicine-Based Multicenter Study. Chest. 2021; 159(3): 1241-1255.
PMid:33227276. https://doi.org/10.1016/j.chest.2020.1 1.013

[9] Jamous F, Meyer N, Buus D, et al. Critical illness due to Covid-19: a description of the surge in a single center in Sioux Falls. S D Med. 2020; 73(7): 312-317.

[10] Yao W, Wang T, Jiang B, et al. Emergency tracheal intubation in 202 patients with COVID-19 in Wuhan, China: lessons learnt and international expert recommendations. Br J Anaesth. 2020; 125(1): e28-e37.

[11] Casey C, David B, Alice Gallo de M, et al. Timing of Intubation in Patients With COVID-19. Chest Journal Critical Care NetWork. March 16, 2021.

[12] Copin M, Parmentier E, Duburcq T, et al. Time to consider histologic pattern of lung injury to treat critically ill patients with COVID-19 infection. Intensive Care Med. 2020; 46: 1124-1126. PMid:32328726. https://doi.org/10.1007/s00134-020-06057-8

[13] Lemmers D, Abu Hilal $M$, Bnà $C$, et al. Pneumomediastinum and subcutaneous emphysema in COVID-19: barotrauma or lung frailty? ERJ Open Res. 2020; 6(4): 00385-2020. PMid:33257914. https://doi.org/10.1183/23120541.00385-2020

[14] Placik D, Taylor W, Wnuk N. Bronchopleural fistula development in the setting of novel therapies for acute respiratory distress syndrome in SARS-CoV-2 pneumonia.Radiol Case Rep. 2020; 15(11): 2378-2381. PMid:32983308. https://doi.org/10.1016/j.ra dcr. 2020.09.026

[15] Belletti A, Palumbo D, Zangrillo A, et al. Predictors of Pneumothorax/Pneumomediastinum in Mechanically Ventilated COVID-19 Patients. J Cardiothorac Vasc Anesth. 2021 Feb 6; S1053-0770(21)00103-8. https://doi.org/10.1053/j.jvca .2021 .02 .008

[16] Eastridge C, Hamman J. Pneumothorax complicated by chronic steroid treatment. The American Journal of Surgery. 1973; 126(6): 784-787. https://doi.org/10.1016/S0002-9610(73) 80071 $-6$ 